\title{
PHENOMENOLOGICAL APPROACHES TO NON-CONCEPTUAL CONTENT
}

\author{
CORIJN VAN MAZIJK
}

M.A. in Philosophy, PhD Student.

University of Groningen (Netherlands), Faculty of Philosophy.

9712HE Groningen, Netherlands.

E-mail: corijnvanmazijk@hotmail.com

Over the past years McDowell's conceptualist theory has received mixed phenomenological reviews. Some phenomenologists have claimed that conceptualism involves an over-intellectualization of human experience. Others have drawn on Husserl's work, arguing that Husserl's theory of fulfillment challenges conceptualism and that his notion of "real content" is non-conceptual. Still others, by contrast, hold that Husserl's later phenomenology is in fundamental agreement with McDowell's theory of conceptually informed experience. So who is right? This paper purports to show that phenomenology does not have to choose between any of these positions. Central to the outline I offer is that there are multiple approaches to non-conceptual content in play today. By separating them we can begin to oversee the diversity of phenomenological contributions to the debate about non-conceptual content. I conclude that current literature presents us with at least three sound phenomenological accounts of non-conceptual content, but also that these are generally not incompatible with conceptualism.

Key words: Phenomenology, non-conceptual content, conceptualism, space of reasons, intentionality, McDowell, Husserl.

\section{ФЕНОМЕНОЛОГИЧЕСКИЕ СПОСОБЫ РАССМОТРЕНИЯ НЕ-КОНЦЕПУТАЛЬНОГО СОДЕРЖАНИЯ}

\section{КОРАЙН ВАН МАЗЕЙК}

Магистр философии, аспирант.

Университет г. Гронинген (Нидерланды), философский факультет.

9712НЕ Гронинген, Нидерланды.

E-mail: corijnvanmazijk@hotmail.com

В последнее время мы имеем дело с возрастающим интересом к теории концептуализма Макдауэлла, в то же время появилось много неоднозначных феноменологических трактовок этой теории. Одни феноменологи считают, что концептуализм подразумевает чрезмерную интеллекутализацию человеческого опыта. Другие, обосновывая свою точку зрения

(C) CORIJN VAN MAZIJK, 2017 
ссылками на тексты Гуссерля, полагают, что теория наполнения Гуссерля ставит концепутализм под вопрос, и что его понятие «реальное содержание» - не-концептуально. Другие же, напротив, полагают, что в своих принципиальных моментах поздняя феноменология Гуссерля согласуется с теорией концептуально информированного опыта Макдауэлла. Так кто же прав? В своей статье я намереваюсь показать, что феноменологии нет необходимости совершать выбор между этими двумя точками зрения. Главное, на что мне хотелось бы обратить внимание, это то, что в настоящее время существует большое множество мнений по поводу вопроса о не-концептуальном содержании. Если их проанализировать, то мы столкнемся с различными феноменологическими подходами в дискуссии о не-концепутальном содержании. В своей статье я прихожу к выводу, что современная исследовательская литература занимается, по крайней мере, тремя феноменологическими подходами к не-концепутальному содержанию. Это, однако, не означает, что эти подходы принципиально несовместимы с концепутализмом.

Ключевые слова: Феноменология, не-концептуальное содержание, концептуализм, пространство смыслов, интенциональность, Макдауэлл, Гуссерль.

\section{INTRODUCTION}

McDowell's Mind and World (McDowell, 1996) recently provoked considerable discussion among philosophers working in a broadly phenomenological tradition, of which the recent collection of essays The McDowell / Dreyfus-Debate (McDowell, 2013) is probably the most noteworthy display. McDowell's central thesis in Mind and World is that the contents of experience are conceptual. A number of theories of non-conceptual content pre-date this thesis. The past decades have seen considerable scholarly effort in analytic philosophy of mind to develop an account of nonconceptual content. Starting with Evans's Varieties of Reference (Evans, 1982), the idea of non-conceptual content was popularized by among others Cussins (Cussins, 1990), Crane (Crane, 1992), Peacocke (Peacocke, 1992) and Bermúdez (Bermúdez, 1994; Bermúdez, 1995). The concept was subsequently taken up in debates about phenomenal content, where it is now often accepted by both representationalists (Dretske, 1995; Tye, 1995; Lycan, 2015) and phenomenalists (Block, 1995).

According to Bermúdez's early and still popular definition, a non-conceptual content is one that represents the world without demanding that its bearer should possess the concepts required to specify that content (even though s/he may in fact possess them) (Bermúdez, 1994, 403). By the same rule, a conceptual content would be one the subject cannot have without possessing concepts that could specify the content. In other words, conceptualism is simply the doctrine that the contents of experience would not have been the way they are without a subject possessing 
the relevant concepts required to explicate those contents in a judgment. Whether or not one accepts the conceptualist doctrine depends to an important degree on certain methodical and conceptual commitments. For instance, whether one includes $^{1}$ or excludes ${ }^{2}$ sub-personal content, whether one is driven by empirical ${ }^{3}$ or phenomenological ${ }^{4}$ motives, and how one defines notions such as content and concept.

In the phenomenological tradition McDowell's rejection of non-conceptual content has been taken up in very different ways. One of the best represented parties takes conceptualism as a (possibly Cartesianist) over-intellectualization of human experience (Dreyfus, 2013; Schear, 2013; Siewert, 2013). They believe phenomenological reflection reveals everyday forms of sense-making that one cannot appropriately address as conceptualized. Hopp (Hopp, 2010; Hopp, 2011) supports phenomenological non-conceptualism by arguing that McDowell's conceptualism cannot account for what Husserl in Logical Investigations calls "fulfillment". Also, Crane (Crane, 1992; Crane, 2013) claims that cases of perceptual illusion must involve non-conceptual content similar to Husserl's notion of "real content". Barber (Barber, 2008) and Mooney (Mooney, 2010), on the other hand, maintain that Husserl's later phenomenology supports McDowell's conceptualism.

The central aim of this paper is to bring structure to the wide diversity of phenomenological contributions to this debate. There has been a great deal of misunderstanding among phenomenologists regarding what it is conceptualists like McDowell are after, and phenomenological non-conceptualists often appear to have very different agendas. In this paper I explore such differences. On this basis, I subsequently distinguish three phenomenological approaches to nonconceptual content: the static approach, the hyletic approach, and the genetic approach. Separating these approaches not only helps bringing to light the great variety of phenomenological contributions, but also clarifies the extent to which phenomenologists have succeeded in providing arguments against conceptualism. Further phenomenological research regarding non-conceptual content should therefore take these divides into account.

1 As does Bermúdez (1995).

2 As does McDowell $(2009,271-272)$.

3 For instance: Block (1995; 2003), Bermúdez (1994; 1995), Dretske (1995), Tye (1995) and Lycan (2015).

4 Among others: Crane (1992; 2003; 2013), Dreyfus (2005; 2013), Hopp (2010; 2011), Doyon (2011), Schear (2013), Siewert (2013). 
In his much celebrated book Mind and World, McDowell aims to develop a satisfactory understanding of the relation between thought and experience with respect to problems of belief justification. His principal concern is to offer an account for how an experience can provide warrant for a belief. The very problem at stake, McDowell believes, is a conceptual one that we inherited from modern philosophy. It can only be solved by reconsidering the fundamental relation between thought and perception. The idea of conceptual capacities operative in receptive experience is supposed to do just that.

Let us first consider this conceptual problem in more detail, given that McDowell frames his conceptualism as a response to that. According to McDowell, twentieth century epistemology has suffered from a certain dilemma regarding how or by what a belief can be justified. This dilemma finds its roots in a separation of two realms of being characteristic of modern philosophy. On a (somewhat simplified) empirical foundationalist account, sense data provide us simple ideas that are causally related to external reality yet also inform our spontaneous thought. On this picture, sense data are somehow conveniently two-legged: while informing spontaneous thought, they also offer a foothold in a lawful, external reality.

The dilemma McDowell identifies concerns the different roles one can assign to sense experience. If we grant sensations the double role just outlined, we admit that experience has epistemic efficacy; it can provide us warrants for beliefs. To this extent, experiences belong to the "space of reasons". Yet at the same time, sense data also belong to external, physical reality. They are bare, natural "givens", and to that extent they are part of the "space of nature". Like others before him, among others Sellars (Sellars, 1997) and Evans (Evans, 1982), McDowell deems this double role of sensations unacceptable. The idea of conceptual capacities operative in experience is in part a response to this fallacious model.

On the empiricist picture just sketched, sensations belong to two images of reality at once: the "space of nature", as an image ruled by natural laws, and the "space of reasons", as a realm of human action and responsibility. McDowell follows Sellarsian tradition by referring to this notion of sensation as the "Myth of the Given". To invoke the idea of a given, according to McDowell, means to extend the space of justification more widely than the space of reasons, that is, into the realm of causal nature (McDowell, 1996, 7). The problem McDowell has with this is that a conception of causally impinging sensations can only yield "exculpations where 
we wanted justifications" (McDowell, 1996, 8). A belief may be caused by a natural event; it is not thereby justified by it.

To avoid a Given, it should therefore be granted that whatever is located in the space of nature cannot function as a reason or belief in the space of reasons. This, however, brings us to the other horn of the dilemma. For it appears that if we drop the Given we must opt for a coherentist account such as Davidson's (Davidson, 1986), according to which beliefs can be justified by other beliefs only. McDowell seems to think this alternative does not fare much better than the empiricist picture: "coherentist rhetoric suggests images of confinement within the sphere of thinking, as opposed to being in touch with something outside it" (McDowell, 1996, 15). Coherentism, or so McDowell suggests, denies our rational faculties access to the empirical world and is therefore prone to skepticism.

The dilemma to which conceptualism responds has now loosely been set: either we commit to a Given, or we lose the idea of thought-exercises onto a world of experience. Neither of these options seems very appealing. What is needed, on McDowell's reading of the problem, is a philosophical explanation of man's place in reality that does not commit a naturalistic fallacy (as in early modern empirical foundationalism) but also does not suggest a confinement imagery (as does coherentism). In brief, in order to circumvent the ongoing oscillation between these two positions, McDowell proposes that we regard intuition as already invested by the relevant conceptual capacities that could be put into play upon a discursive apprehension of what we experience. Experiences (or "intuitions" in the Kantian jargon) unguided by concepts - "blind intuitions", as Kant said - do not exist ${ }^{5}$. If we want to think of our thoughts as bearing onto external reality, then we should conceive of intuition and sensation as already conceptually structured. This way, we can maintain thought's bearing on reality without committing to a given.

Put as simple as possible, McDowell's claim is roughly that because perceptual experience is thus endowed with conceptual capacities, i.e. has conceptual content, we have avoided invoking a non-conceptual Given to mediate the space of reasons and outer reality. At the same time, the very idea of intuition, as we also find it in Kant's transcendental philosophy, should suffice to preserve the idea of a touch of our senses upon the external world, thus helping us to avoid a coherentism or "Cartesian" internalism. Intuition preserves a touch of our senses upon an external world, even

5 See especially Lecture I of Mind and World (McDowell, 1996), also A50/B74 of Kant's first Critique (Kant, 1998). 
though, simultaneously, the immediate contents of intuition are conceptual, thus avoiding the Given. It can be helpful to note here that the external world in case is not one located outside of the realm of the conceptual (McDowell, 1996, 54). In a way, on McDowell's picture, reality itself is conceptually invested, but it is nonetheless an external reality and one that we are principally in touch with through sensibility ${ }^{6}$.

The idea of conceptually "saddled" intuition needs further characterization and this is offered by reference to our so-called second nature, where McDowell's notion of Bildung first comes to the fore (McDowell, 1996, 84-86; McDowell, 1998, 184188). The notion of Bildung plays a very important role in McDowell's philosophy. It is supposed to explain how our natural sensibility (first nature) can involve processes that are in a sense non-natural (second nature), insofar as they belong to the space of reasons. Bildung, as a natural potentiality that we are born with for the cultural development of a space of reasons, serves in a way to keep the space of reasons down to earth. On the one hand, McDowell thinks that "spontaneity-related concepts cannot be duplicated in terms of concepts whose fundamental point is to place things in the realm of law" (McDowell, 1996, 74). Conceptual exercises, then, cannot be explained in terms of the space of nature. Yet McDowell does not want to suggest that the space of reasons is entirely "extra-natural" either, as that would make conceptualism a form of "rampant Platonism". Crudely put, the notion of Bildung, functions as a kind of bridge (at least conceptually speaking) between these two paradigms of explanation.

McDowell thus aims to conceive of two heterogeneous "spaces of intelligibility". So how, then, can conceptual capacities operate onto sensibility, which consists of natural operations? The answer is that McDowell thinks of the space of nature as not exclusively a lawful space, and therefore, in some sense at least, it could involve conceptual capacities, such that "a concept of spontaneity that is sui generis [...] can nevertheless enter into characterizing states and occurrences of sensibility" (McDowell, 1996, 76). Put differently, by widening the standard conception of the space of nature - it is construed as broader than the realm of $\mathrm{law}^{7}-\mathrm{McDowell}$

\footnotetext{
6 Substantial confusion might have been avoided had McDowell been clearer about this. For one, MacDonald's (2006) discussion with McDowell (2006a) appears to rest on confusion regarding the meaning of McDowell's externalism.

7 "So long as we do not dispute that something's way of being natural is its place in the realm of law, the concept of spontaneity functions in the space of reasons, so as to rule out the possibility that spontaneity might permeate the operations of sensibility as such" (McDowell, 1996, 75). Also: "We can acknowledge the [...]
} 
thinks he can maintain that conceptual capacities are "actualizations of our nature" - and to this extent that rampant Platonism is avoided — while at the same time deny that they are purely natural - to the extent that a "bald naturalism" (which reduces all talk of reasons to nature) is also avoided.

McDowell certainly is not unaware that what he opts for appears ambivalent: "...it looks as if we are picturing human beings as partly in nature and partly outside it" (McDowell, 1996, 77). If McDowell's conceptualist picture is to cohere, he needs to say more about the exact relation between the natural and non-natural realms, i.e. between the spaces of reasons and nature - and this is where the notion of Bildung comes to the fore.

According to McDowell's sketchy specification of Bildung, human beings engage in a process of cultural development by which they attain a second nature; a vast collection of habits of thought that structure experiences independently of the agent's deliberation. Such a second nature allows for "having one's eyes opened to reasons" (McDowell, 1996, 84), i.e.: for having sensory experiences that are reasons for belief and that have the appropriate conceptual structure to make them figure in belief states. The idea of rejecting the given is not supposed to involve denying that we have a first nature. Rather, McDowell's claim is that once a rational agent has been raised with second nature, the contents of his/her experience are, at least in one sense, non-natural, in that they belong to the (non-Platonic) realm of reasons ${ }^{8}$.

It is good to emphasize that there is something deeply un-phenomenological about McDowell's distinction between spaces of reasons and nature and the role Bildung plays therein. For McDowell, sensibility is principally a matter of nature. That is, it can be assessed unproblematically in naturalistic terms. For one, animals, McDowell notes, "are natural being and no more"; they are "entirely contained within nature"; their "sensory interactions with their environment are natural goings-on" (McDowell, 1996, 70). The conceptual sphere of reasons, by contrast, is the only thing that cannot be so understood. As McDowell puts it, there are only "some secondnatural phenomena that [...] natural science cannot accommodate, on the ground that their intelligibility is of the special space-of-reasons kind" (McDowell, 2006b, 236, my italics). The adjective "special" here can be substituted with "conceptual". Interestingly, McDowell here submits that the conceptual is special not just for its

realm of natural law, that is empty of meaning, but we can refuse to equate that domain of intelligibility with nature, let alone with what is real" (McDowell, 1996, 109).

8 See also McDowell (1998, 167-197) for a more elaborate exposition of two sorts of naturalism. 
role in justifying beliefs. Moreover, it is taken to be the only aspect of our experiential lives that natural science cannot account for.

On McDowell's picture, then, we have two distinct realms of explanation: a space of reasons and a space of nature. In between them, so to say, we have a notion of Bildung which suggests a "genesis" of that which we cannot explain in lawful terms (the conceptual space of reasons) from the natural realm. So what could be un-phenomenological about this? Crucially, phenomenology - at least in Husserl's paradigmatic form - rejects the idea of a selective application of natural science to sensibility and a selective application of epistemology to conceptual structures. From Husserl's point of view, the very distinction betrays the inability to see the unity of conscious life throughout both its subjective and objective aspects, and between its lower level "natural" accomplishments and its higher level "rational" ones. Husserl, in fact, criticizes traditional psychology roughly for a picture similar to the one McDowell appears committed to. As Husserl notes, the main mistake of naturalistic psychology is "that it posited the passivity of association and of the whole psychic life unfolding without the activity of the I at the same level with the passivity of the physical natural process" (Husserl, 2004, 333). "However", Husserl continues, "passive motivation is, like all spiritual causality [...] a sphere of understandability standing under pure essential laws and, therefore, having a completely different meaning than natural causality and natural lawfulness" (Husserl, 2004, 333).

What Husserl means is that the structure of that space which cannot be made understandable in terms of the kind of intelligibility that belongs to the realm of law is not marked exclusively by conceptual or higher level cognitive activity. Whereas for McDowell only some phenomena cannot be accommodated by natural science and therefore belong to the special space of reasons, Husserl contends that the entire distinction between supposed natural contents of consciousness and higher level contents of the space-of-reasons kind is artificial. There is no way to limit the spiritual life to a rational responsiveness to reasons and to demarcate it from lower level accomplishments.

From a phenomenological point of view, then, the distinction between a space of reasons - which only includes conceptual structures - and a space of nature - which includes natural sensibility - is artificial. There is, in terms of the intelligibility belonging to nature, no radical distinction to be made within the contents of consciousness. Husserl holds that the whole streaming life of consciousness must be said to have its own essence, all the way down into the operations of passive sensibility - operations McDowell takes to belong to 
lawful nature - and must be understood in conformity with that essence if true intelligibility is to be acquired.

The very idea of conceptualism therefore operates on a conceptual scheme that is entirely unknown to phenomenology - or at least Husserl's systematic version of it. Against Husserl, McDowell believes that if we want to maintain the idea of a rational constraint from experienced reality, then the idea of conceptual capacities operating in sensibility must be the only option. This is because McDowell does not accept the possibility that the space of reasons includes anything other than the conceptual, since all lower level accomplishments of consciousness belong simply to the space of nature. Only the conceptual has its place in the space of reasons, and this is why "we cannot really understand the relations in virtue of which a judgment is warranted except as relations within the space of concepts" (McDowell, 1996, 7).

Broadly construed, then, the motivation behind McDowell's conceptualism is to provide an alternative picture of the relation between mind and world which puts an end to the oscillatory state between empirical foundationalism and coherentism. The oscillation is between our commitment to a fallacious myth of the given and a picture which cuts us loose from reality. On the first view, the space of nature spills over into the space of reasons; on the second picture, our minds float freely over and above reality. The new images suggests that we are in touch with reality, but that this very touch is conceptually invested.

I think this should more or less capture the core of the conceptualist thesis as McDowell defends it. However, on a closer reading, it shows that McDowell says a number of different things with respect to what the conceptual investment of experiences amounts to exactly. With regard to this, I think it is worth distinguishing between three different conceptualist theses.

First, we can distinguish what I call hard conceptualism. According to hard conceptualism, the contents of experience simply are concepts. This is an intuitively implausible position. McDowell, however, appears to express sympathy for it in at least two places in Mind and World. Right in the opening of the book, he asserts that "relations in virtue of which a judgment is warranted" can only be understood "as relations within the space of concepts" (McDowell, 1996, 7). Further on, he repeats this idea negatively: "if experiences are extra-conceptual, they cannot be what thoughts are rationally based on" (McDowell, 1996, 68). This appears to suggest that only concepts can serve as reasons for beliefs, which would make perceptual content quite literally a type of concept. 
Many critics of McDowell have taken him to support hard conceptualism. But the previous remarks notwithstanding, McDowell does not appear to endorse hard conceptualism. McDowell is not out to suggest that there are no phenomenological differences between thinking and perceiving, i.e. that the content of a thought is identical to the content of a perception. If we look at those fragments where McDowell explicitly addresses the meaning of conceptualism, we find him endorsing something weaker than hard conceptualism. Let us consider the following three fragments:

The way I am exploiting the Kantian idea of spontaneity commits me to a demanding interpretation of words like "concepts" and "conceptual". It is essential to conceptual capacities, in the demanding sense, that they can be exploited in active thinking. (McDowell, 1996, 47, my italics)

An intuition's content is all conceptual, in this sense: it is in the intuition in a form in which one could make it, that very content, figure in discursive activity. (McDowell, 2009, 265, my italics)

[This] is what it means for capacities to be conceptual in the relevant sense: they are capacities whose content is of a form that fits it to figure in discursive activity. (McDowell, 2013, 42, my italics)

These three fragments all state that it is intuition's openness to conceptual explication - not its being a concept - which defines its conceptual nature. I call this thesis weak conceptualism. According to weak conceptualism, the contents of experience are such that they can be taken up into rationality, and are conceptual just to that extent. Weak conceptualism in the sense specified only demands openness to reason of all experience. I believe weak conceptualism is the principal thesis McDowell wishes to defend.

Lastly, a third conceptualist thesis is worth specifying. On what I call full conceptualism, the contents of experience are conceptual in this sense: they can be taken up into judgments in the way weak conceptualism specifies, but for that to be possible at all, rational capacities must already figure in them. The full conceptualist doctrine thus adds a conditioning factor to the weak definition, namely that some conceptual capacities must be at work in experience in order to make it open to reason in the first place.

It is not entirely clear to me what role full conceptualism plays in McDowell's conceptualist theory in Mind and World. Although there is frequent mention of conceptual capacities figuring in perception in Mind and World, which thus points to full conceptualism, those places where McDowell explicitly defines conceptualism 
are usually formulations of weak conceptualism, as I showed above. I will not try to resolve this issue here, but instead continue with a perhaps somewhat "generous" reading of McDowell, which subscribes primarily weak conceptualism to him.

\section{PHENOMENOLOGICAL NON-CONCEPTUALISM (1): THE STATIC APPROACH}

In the recent book The McDowell-Dreyfus Debate, Dreyfus turns to the works of Heidegger and Merleau-Ponty for examples of pre-reflective, skillful action in order to challenge McDowell's conceptualism. According to Dreyfus, the idea that the understanding is "inextricably implicated in the deliverances of sensibility" (McDowell, 1996, 46) is fundamentally at odds with the phenomenological description of what he calls skillful or absorbed coping9.

Drawing on Heidegger, Dreyfus shows that we do not have to think about the doorknob on the door in order to use it to enter or leave a room. In fact, the doorknob does not have to be apprehended at all. Absorbed copings, on this existential-phenomenological understanding, are mindless activities; they involve no objectification and therefore no rationality. For Dreyfus, this means that it is inappropriate to characterize their contents (in so far as there would be any content here at all, on his view) as conceptual. To acknowledge the phenomenological structure of absorbed coping is to deny the permanent presence of operations of the understanding. The conclusion Dreyfus but also Schear (Schear, 2013) draw from this is that McDowell's theory of conceptual intuitions rests on an over-intellectualization of human experience (Schear, 2013, 294-299).

Does this criticism pose a genuine problem for McDowell's conceptualism? The basic structure of the argument just outlined appears to be as follows ${ }^{10}$ :

(P1) The involvement of concepts requires an intentional structure founded upon a distance between a subject and an object

(P2) Absorbed or skillful coping does not involve an intentional structure founded upon a distance between a subject and an object

(C1) Absorbed or skillful coping does not involve concepts, i.e. is non-conceptual

The argument against conceptualism rests in part on the acceptance of premise (1): that the involvement of concepts demands some kind of a critical stance that

I also discuss Dreyfus's case for non-conceptual content in Mazijk (2014a; 2014b).

${ }^{10}$ I base this syllogism largely on the one Schear $(2013,294)$ uses in his reading of Dreyfus. 
is typical for judgment. That presupposition, however, is denied by a number of philosophers, among others Noë (Noë, 2013), Crane (Crane, 2013), but also McDowell (McDowell, 2013) himself. As I pointed out already in the previous section, the conceptual capacities McDowell sees integrated in experience do not depend so much on a specific phenomenology of experience; they do not require that a subject/ object-distance typical of judgment is involved.

McDowell wants to convince us that experience is 'saddled' with conceptual capacities due to our cultural upbringing, which results in the openness of experience to reasons. According to what I called weak conceptualism, the contents of experience (i) have the appropriate structure to figure in a judgment while full conceptualism adds that this (ii) is due to the involvement of rational capacities in them. In the case of skillfully opening a door, (i) is supported by the fact that one can make the skillful action of using the doorknob figure in a judgment. Also, one can give reasons for having performed this action in hindsight. This particular experience is therefore not beyond rationality. Moreover, it seems that if I would I have lacked all knowledge about how doorknobs work, the building I am in, and about the room behind the door, then the unreflective experience of opening the door might well have had a different content. This indicates that some sort of rationality may in fact have figured passively in this skillful action after all.

A second example Dreyfus discusses concerns a game of chess (Dreyfus, 2013, 35; McDowell, 2013, 46-50). Dreyfus holds that a chess master may be "directly drawn by the forces on the board" without making his move for any consciously entertained reason (Dreyfus, 2013, 35). Again, the example is supposed to show that rational capacities are not necessarily involved in experience, because meaningful acts can also be executed passively.

But the argument is not very convincing. McDowell's response is simply that "cultivated rationality [...] is also operative in his [the chess master] being drawn to make his move by the forces on the board" (McDowell, 2013, 48). McDowell therefore does not reject the phenomenology of skillful coping as Dreyfus argument presupposes. He simply claims that forces, too, are permeated by rationality in the same sense in which opening doors is. McDowell's conceptualism is thus left unchallenged by the arguments put forward by Dreyfus ${ }^{11}$.

${ }^{11}$ McDowell in fact endorses a broadly Gibsonean account of experience, which might bring him considerably closer to Dreyfus than the latter believes. See McDowell $(1994,202)$. 
Hopp (Hopp, 2010; Hopp, 2011) provides a different argument against McDowell based on Husserl's early theory of fulfillment in Logical Investigations ${ }^{12}$. To put it simply, Husserl thinks thought by itself can be merely empty. The mere thought about a coffee mug on my desk cannot does not give me the coffee mug "in the flesh" as a perception of it would. Perception can deliver a surplus to the emptiness of thought in case a synthesis between the two intentions takes place. For instance, when I think about a particular coffee mug and subsequently turn my head to perceive that very mug, a synthesis of recognition takes place between these two intentions. The experience I am now undergoing could not have been established would I merely have had the empty thought of the coffee mug. Although in case of a vivid memory a "quasi-fulfillment" between the thought and the memory may take place, only perception can make that distinctive contribution in the process of verifying empty intentions. Hopp's argument is that perception must therefore have extra-conceptual content, since the conceptual contents of thought alone can never deliver that contribution (Hopp, 2011, 103-148).

Hopp (Hopp, 2011), then, claims that McDowell is unable to address the different epistemic roles played by perception and thought respectively. Because conceptualism addresses the contents of perception as conceptual, it fails to do justice to the important justificatory differences between perception and thought.

I think Hopp's point that perceptual fulfillment involves a non-conceptual surplus is correct. But it seems Hopp's discussion circumvents the question how perception can accomplish the fulfillment of thought in the first place. Conceptualism, by contrast, does provide an answer to that question. It offers an explanation as to why an intuitively presented content can figure in perceptual judgment - namely because the perception already involves the passive activation of conceptual capacities. So whereas Hopp thinks a phenomenological account of fulfillment forces us to speak of non-conceptual content, McDowell ascribes the very possibility of an immediate perceptual warrant to its conceptual content.

The way I see it, the reason the arguments developed by Dreyfus and Hopp do not really threaten McDowell's position is that both operate with a static approach to non-conceptual content. The reason for calling their approaches "static" is that their definitions of non-conceptual content do not draw on one's experiential past or "second nature". For Dreyfus, a content is non-conceptual if the respective act

${ }^{12}$ I also discuss Hopp's argument in Mazijk (2015). 
lacks an active subject. For Hopp, an experience involves non-conceptual content if it is capable of intuitively fulfilling thought intentions. Neither of these notions takes interest in the passive operations of rational capacities in experience, which is a central tenet of conceptualism.

\section{PHENOMENOLOGICAL NON-CONCEPTUALISM (2): THE HYLETIC APPROACH}

A number of philosophers and phenomenologists have appealed to cases of illusion to illustrate that perception must have non-conceptual content (Crane, 1988; Crane, 1992; Bermúdez, 1995; Bermúdez \& Cahen 2011; De Vries, 2011). The core idea here is that to make sense of illusion, we need to posit two levels of representation. One of these levels presents the intentional object the subject is directed at; the other is a sub-personal representational content.

Crane (Crane, 1992) argues that the famous Müller-Lyer illusion shows us the existence of non-conceptual content. Even when confronted with evidence that both lines are equally sized, one remains to see one as being longer than the other. We must, then, distinguish between what the subject intends - two lines of different lengths - and a sub-personal level of representation, in order to account for the fact that there is a sense in which both lines are given as of equal length. As De Vries (De Vries, 2011, 49-51) proposes, this thought can be taken two ways: either such sub-personal representational contents are only involved in cases of illusion, or we take them to be permanently operative. Since the second is obviously more plausible, all perception must have non-conceptual content.

In a similar way, though from a somewhat different angle, Dretske (Dretske, 1995) separates "systemic" from "acquired" representations. He illustrates that with an example of two dogs which are conditioned differently. Whereas one dog is trained to salivate upon hearing a clarinet play any musical note whatsoever, the other does the same thing on hearing a C-note regardless of the instrument on which it is played. Now consider a C-note is being played on a clarinet, thus causing both dogs to salivate. According to Dretske, both dogs will have different "acquired" representations: one intends a clarinet, the other a C-note. But at a non-conceptual level, they have identical representations (as they are exposed to the same sound data).

A third variation of this argument appears in Crane (Crane, 2013), where Crane draws on a Husserlian distinction between "real" and "general" content. Husserl writes: "Every chance of alteration of the perceiver's relative position alters 
his perception, and different persons, who perceive the same object simultaneously, never have exactly the same perceptions. No such differences are relevant to the meaning of a perceptual statement” (Husserl, 1984, VI \$4).

Husserl suggests that although one is typically related to a single object over the course of a perceptual act, the exact ways in which it is given changes incessantly. The side of the object directly given changes as one moves around, but this does not change the object of perception. It seems impossible to imagine that for every slight variation in the "how" of a perceptual appearance there would be a different object given intentionally. Therefore, although the contents of experience might still be conceptual at the level of object-representation, perception must also involve content which is constantly changing. Husserl usually speaks of "real" or "hyletic" contents here. Crane, somewhat unfortunately perhaps, calls them phenomenological contents (Crane, 2013, 245).

Since, as I argued earlier, openness to judgment is the principal criterion for conceptual content on McDowell's account, it might seem that the arguments discussed offer resources to rebut conceptualism. Since (as quoted above) "every chance of alteration of the perceiver's relative position alters his perception", and these continuous changes of content cannot all be conceptualized by the ego-subject, they have to be non-conceptual.

As with the arguments developed by Dreyfus and Hopp, I believe Husserl's account of hyletic content convincingly proves the merits of positing non-conceptual content for a phenomenological theory of experience. However, I think it is doubtful whether it presents any serious obstacles to conceptualism, at least to the extent I outlined the argument above. McDowell could simply reply that hyletic content is not a part of the experience of rational animals in the sense he is after. Husserl too notes that hyletic contents are constitutive of intentionality but not themselves intentional (Husserl, 1983, 203). Without any further elaborations with respect to the role hyletic contents play in justifying beliefs on Husserl's account, it could fairly easily be argued that they are plainly a form of sub-personal "psychological" content.

To be fair, I strongly doubt Husserl would accept reducing hyletic content to epistemically superfluous contents that can be explicated sufficiently in the natural realm of law. On Husserl's account, hyletic content is not sub-personal psychological content; it contributes to a transcendental clarification of meaning and knowledge. But to develop that point properly would, I think, require a much more thoroughgoing critique of McDowell's account of spaces of reasons and nature from the viewpoint of Husserl's transcendental phenomenology. I will not attempt 
to do so here. As it stands, the hyletic approach to non-conceptual content does not necessarily threaten McDowell's idea that experience makes something available that is open to rational scrutiny, since a conceptualist could set such contents aside as epistemically irrelevant sub-personal processes.

\section{PHENOMENOLOGICAL NON-CONCEPTUALISM (3): THE GENETIC APPROACH}

There is another potential phenomenological path to non-conceptual content which has thus far been ventured less, but which should nonetheless be demarcated from the approaches discussed thus far. This third approach, which I address as the genetic approach, is best illustrated by means of Husserl's later so-called "genetic phenomenology".

In his later work, Husserl develops a new approach to a transcendental clarification of meaning and knowledge. In these later writings, which include the course lectures Analyses Concerning Passive and Active Synthesis (1918-1926), Formal and Transcendental Logic (1929), and Experience and Judgment (1939), the task of a transcendental clarification becomes a search for a so-called "genesis". This genesis is sought above all in concrete receptive experience. Without here entering into the details of these analyses, Husserl's claim is roughly that passive, prepredicative experience offers the ground of all fundamental logical-conceptual categories. Passivity, on Husserl's account, "is the mother soil [Mutterboden] of knowledge" (Husserl, 2004, 332). The central point of these analyses is that passive experience brings about a complexly pre-structured world prior to conceptual thought. Prima facie, this account directly opposes McDowell's to this extent that passive experience does not get its complexity from rational capacities, but prestructures the world in pre-predicative ways from out of itself.

Recent debates about non-conceptual content in Husserl's later work focus to an important extent on the methodology of Husserl's analyses on passivity. What is at stake here is to what extent or in what sense passivity for Husserl would be an abstraction from actual experience. This discussion in part revolves around the question of the pervasive impact of conceptual thought onto passivity (secondary passivity). As Barber notes, "Husserl's genetic method [...] could be taken to imply that the contributions of receptivity and spontaneity are never distinct" (Barber, 2008 , 86). In another article, Mooney adds his own turn of phrase, tating that for Husserl to perceive without latent concepts would be an "epistemically innocent" 
ability which one "loses for good" after childhood (Mooney, 2010, 39). Barber (Barber, 2008) Mooney (Mooney, 2010) both end up supporting Husserlian conceptualism by crediting the latter's analyses on fields of sensations abstractions from actual, mature human experience. Much of this debate rests on the following fragment from Experience and Judgment:

When we distinguish [...] receptive experience, on the one hand, and [...] predicative spontaneity, on the other, this distinction of levels should not be construed as if the different operations were somehow separate from each other. On the contrary, things which must be taken separately for the sake of analysis and which, genetically, are recognized as belonging to different levels of objectification are as a rule actually closely entwined. (Husserl, 1997, 203-204)

The conceptualist's interpretation of this fragment - call it the abstraction thesis - reads that concepts must play some part already in passivity, given Husserl's remark that both are actually closely entwined. For that reason, an original passivity as illustrated by Husserl's analyses of fields of sense is in reality an abstraction. They might obtain for the experiences we had at some point in the past, but they are no longer operative in mature consciousness. It can subsequently be argued that Husserl is a conceptualist after all, because for adult human beings perception is permeated with rational capacities through and through. It is only by taking Husserl's abstract discussions too literally that phenomenology could appear to object to conceptualism.

Those adhering to the abstraction thus believe that Husserl supports conceptualism even though it may not appear so at first sight. Apart from Husserl's own remarks on the way different levels of objectification are actually closely entwined in real life activity, there are doubtlessly passages scattered among Husserl's work which appear to commit him to conceptualism of some sort. Husserl notes, for instance, that perception is a field of "possible substrates of cognitive activities" (Husserl, 1997, 37), that it is "impregnated by the precipitate of logical operations" (Husserl, 1997, 42), and that "concepts are not just our business" but instead "belong to the world [...], are intrinsic to its very being" (Husserl, 2001b, 92) ${ }^{13}$. At least where our conscious lives as responsible agents is concerned, Husserl seems to endorse some form of conceptualism.

13 „Die Begriffe sind nicht unsere Sache, die nur uns Erkennende angeht. Das Seiende seinerseits ist nicht in sich, den Begriffen fremd. Ferner, erkennen wir begrifflich denkend und einsehend Gesetze, so sind wir nicht Gesetzgeber und die Dinge an sich ohne Gesetze, sondern der Welt selbst als seiender gehören die Gesetze zu, von ihr in ihrem Sein unabtrennbar" (Husserl, 2001b, 92). 
Nevertheless, I find the abstraction thesis not very convincing. This is because it runs against the basics of Husserlian phenomenological methodology. In transcendental phenomenology, there are no questions at all about childlike versus adult consciousness; there is only transcendental consciousness. In transcendental phenomenology one can only investigate what is indubitably given. As Husserl explains in Experience and Judgment, genetic investigation rather involves an additional epoché in transcendental consciousness, by which the phenomenologist disregards higher levels of synthetic achievements in order to get lower level ones better into sight (Husserl, 1997, 56). Hence fields of sense are no abstractions from actual consciousness; they are synthetic and indeed non-conceptual achievements which, as Husserl notes explicitly, are still fully operative in mature consciousness (Husserl, 2001a, 167).

The right way to address the issue of abstraction is, I think, to distinguish between abstraction in two senses: (1) abstracting from what is real (or in the phenomenological case "given") and (2) abstracting in the sense of bracketing certain strata of achievements of consciousness in order to uncover aspects of intentionality that otherwise remain hidden. Only the latter reading is compatible with phenomenological methodology ${ }^{14}$. For that reason, fields of sense might well qualify as non-conceptual operations - although to be sure this does not imply a commitment to a myth of the given, as would be the immediate consequence in McDowell's conceptual scheme.

In spite of my disagreement with Barber and Mooney on the point of abstraction and fields of sense, I think they are on the right track that, at least insofar as we enter the field of attentive perception - which involves the intentional directedness of an ego-subject toward a perceptual object (an intentionality unknown to the radically passive fields of sense) - we are dealing, according to Husserl, with "a world in which cognition in the most diverse ways has already done its work" (Husserl, 1997, 31). One could therefore plausibly maintain that the later Husserl maintains some version of full (and weak) conceptualism. However, to my mind, this would have to be one that restricts the tacit employment of rational operations

\footnotetext{
${ }^{14}$ This second reading allows us to understand Husserl's remarks on abstraction simply as a careful note to the reader that in everyday experience one cannot separate all these layers as neatly as Husserl is forced to represent it by his commitment to analytic precision, without thereby implying abstraction in the first sense. Note that, with regard to the fragment quoted, this much simpler explanation also better fits the context in which the fragment appears, which is right at the opening of Part II of Experience and Judgment, which bridges the analyses of passive to active synthesis.
} 
to perceptually attentive modes of experience, in order to allow for non-conceptual fields of sense ${ }^{15}$.

\section{CONCLUSION}

The aim of this paper was to outline some of the trends of thinking about nonconceptual content in contemporary phenomenology. I outlined different versions of conceptualism and subsequently categorized recent phenomenological engagements in three groups according to how they approach the debate.

Generally speaking, I think ongoing discussions reflect a great deal of creativity among phenomenologically oriented philosophers with respect to debates about conceptualism. I hope the distinctions introduced in this paper help expose the originality of these contributions more clearly. At the same time, ongoing discussions often betray a somewhat simple understanding of McDowell's conceptualist thesis. More specifically, they generally reflect little concern for McDowell's complicated picture of the relations between reasons and nature. The conceptualist thesis is, however, carefully tied into that picture. With such a great variety of interesting contributions now at our disposal, it thus seems that the call for a sustained phenomenological critique of the deeper philosophical commitments that ground conceptualism might still be open.

\section{REFERENCES}

Barber, M. D. (2008). Holism and Horizon: Husserl and McDowell on Non-conceptual Content. Husserl Studies, 24, 79-97.

Bermúdez, J. L. (1994). Peacocke's Argument against the Autonomy of Non-conceptual Content. Mind and Language, 9, 402-418.

Bermúdez, J. L. (1995). Non-conceptual Content: From Perceptual Experience to Subpersonal Computational States. Mind and Language, 10, 333-362.

Bermúdez, J. L., \& Cahen, A. (2011). Non-conceptual Mental Content. Stanford Encyclopedia of Philosophy. Retrieved from https: //plato.stanford.edu/entries/content-nonconceptual/

Block, N. (1995). On a Confusion about a Function of Consciousness. Behavioral and Brain Sciences, 18 (2), 227-287.

Block, N. (2003). Mental Paint. In M. Hahn \& B. Ramberg (Eds.), Reflections and Replies: Essays on the Philosophy of Tyler Burge (165-200). Massachusetts: The MIT Press.

Crane, T. (1988). The Waterfall Illusion. Analysis, 48, 142-147.

Crane, T. (1992). The Non-conceptual Content of Experience. In T. Crane (Ed.), The Contents of Experience (136-157). Cambridge: Cambridge University Press.

15 I have elaborated this account of non-conceptual fields of sense in more detail in: Mazijk (2016). 
Crane, T. (2003). The Intentional Structure of Consciousness. In A. Jokic \& Q. Smith (Eds.), Consciousness: New Philosophical Perspectives (33-57). Oxford, New York: Oxford University Press.

Crane, T. (2013). The Given. In J. K. Schear (Ed.), Mind, Reason, and Being-in-the-World: The McDowell-Dreyfus Debate (229-250). London, New York: Routledge.

Cussins, A. (1990). The Connectionist Construction of Concepts. In M. Boden (Ed.), The Philosophy of Artificial Intelligence (368-440). Oxford: Oxford University Press.

Davidson, D., (1986). A Coherence Theory of Truth and Knowledge. In Ernest LePore (Ed.), Truth and Interpretation, Perspectives on the Philosophy of Donald Davidson (307-319). Oxford: Basil Blackwell.

De Vries, W. (2011). Sellars vs. McDowell: On the Structure of Sensory Consciousness. Diametros, $27,47-63$.

Doyon, M. (2011). Husserl and McDowell on the Role of Concepts in Perception. In B. Hopkins \& J. Drummond (Eds.), The New Yearbook for Phenomenology and Phenomenological Philosophy, XI, 42-74.

Dretske, F. (1995). Naturalizing the Mind. Cambridge, Mass.: The MIT Press.

Dreyfus, H. L. (2013). The Myth of the Pervasiveness of the Mental. In J. K. Schear (Ed.), Mind, Reason, and Being-in-the-World: The McDowell-Dreyfus Debate (15-40). London, New York: Routledge.

Evans, G. (1982). The Varieties of Reference. Oxford: Oxford University Press.

Hopp, W. (2010). How to Think about Nonconceptual Content. In B. Hopkins \& J. Drummond (Eds.), The New Yearbook for Phenomenology and Phenomenological Philosophy,X (1), $1-24$.

Hopp, W. (2011). Perception and Knowledge: A Phenomenological Account. Cambridge University Press.

Husserl, E. (1983). Ideas Pertaining to a Pure Phenomenology and to a Phenomenological Philosophy: First Book: General Introduction to a Pure Phenomenology. The Hague, Boston, Lancaster: Martinus Nijhoff Publishers.

Husserl, E. (1984). Logische Untersuchungen. Zweiter Band: Untersuchungen zur Phänomenologie und Theorie der Erkenntnis (Hua XIX/1, Hua XIX/2). Den Haag: Nijhoff.

Husserl, E. (1997). Experience and Judgment: Investigations in a Genealogy of Logic. Evanston: Northwestern University Press.

Husserl, E. (2001a). Analyses Concerning Passive and Active Synthesis: Lectures on Transcendental Logic. In R. Bernet (Ed.), Collected Works. Vol IX. Dordrecht, Boston, London: Kluwer Academic Publishers.

Husserl, E. (2001b). Natur und Geist: Vorlesungen Sommersemester 1927 (Hua XXXII). Dordrecht: Springer.

Husserl, E. (2004). Einleitung in die Ethik. Vorlesungen Sommersemester 1920 und 1924. Dordrecht, Boston, London: Kluwer Academic Publishers.

Kant, I. (1998). Critique of Pure Reason. Cambridge, New York, Melbourne: Cambridge University Press.

Lycan, W. G. (2015). Representational Theories of Consciousness. Stanford Encyclopedia of Philosophy. Retrieved from http://plato.stanford.edu/entries/consciousness-representational/

MacDonald, C. (2006). Self-Knowledge and Inner Space. In C. MacDonald \& G. MacDonald (Eds.), McDowell and His Critics (73-89). Oxford: Blackwell Publishing.

Mazijk, C. van (2014a). Kant, Husserl, McDowell: The Non-Conceptual In Experience. Diametros, 41, 99-114. 
Mazijk, C. van (2014b). Phenomenology and Non-Conceptual Content [Review of the book Mind, Reason, and Being-In-the-World: The McDowell/Dreyfus-Debate, by J. K. Schear's (2013)]. Metodo. International Studies in Phenomenology and Philosophy, 2 (2), 273-278.

Mazijk, C. van (2015). Walter Hopp: Perception and Knowledge: a Phenomenological Account. Phenomenology and the Cognitive Sciences, 14 (4), 1185-1191.

Mazijk, C. van (2016). Kant and Husserl on the Contents of Perception. Southern Journal of Philosophy, 54 (2), 267-287.

McDowell, J. H. (1986). Singular Thought and the Extent of Inner Space. In P. Pettit \& J. H. McDowell (Eds.), Subject, Thought, and Context (137-168). Oxford: Claredon Press.

McDowell, J. (1994). The Content of Perceptual Experience. The Philosophical Quarterly, 44 (175), 190-205.

McDowell, J. (1996). Mind and World. Cambridge, MA; London: Harvard University Press.

McDowell, J. (1998). Two Sorts of Naturalism. In McDowell, J. Mind, Value, and Reality (167-197). Cambridge, Massachusetts, London: Harvard University Press.

McDowell, J. (2006a). Response to Cyntia MacDonald. In C. Macdonald \& G. MacDonald (Eds.), McDowell and his Critics (89-94). Oxford: Blackwell Publishing.

McDowell, J. (2006b). Response to MacDonald. In C. MacDonald \& G. MacDonald (Eds.), McDowell and his Critics (235-240). Oxford: Blackwell Publishing.

McDowell, J. (2009). Having the World in View: Essays on Kant, Hegel, and Sellars. Cambridge: Harvard University Press.

McDowell, J. (2013). The Myth of the Mind as Detached. In J. K. Schear (Ed.), Mind, Reason, and Being-in-the-World: The McDowell-Dreyfus Debate (41-58). London, New York: Routledge.

Mooney, T. (2010). Understanding and Simple Seeing in Husserl. Husserl Studies, 26, 19-48.

Noë, A. (2013). On Overintellectualizing the Intellect. In J. K. Schear (Ed.), Mind, Reason, and Being-in-the-World: The McDowell-Dreyfus Debate (178-193). London, New York: Routledge.

Peacocke, C. (1992). A Study of Concepts. Cambridge MA: MIT Press.

Schear, J. K. (2013). Are We Essentially Rational Animals? In J. K. Schear (Ed.), Mind, Reason, and Being-in-the-World: The McDowell-Dreyfus Debate (285-302). London, New York: Routledge.

Sellars, W. (1997). Empiricism and the Philosophy of Mind. Cambrige, MA: Harvard University Press.

Siewert, C. (2013). Intellectualism, Experience, and Motor Understanding. In J. K. Schear (Ed.), Mind, Reason, and Being-in-the-World: The McDowell-Dreyfus Debate (194-226). London, New York: Routledge.

Tye, M. (1995). Ten Problems of Consciousness: A Representational Theory of the Phenomenal Mind. Cambridge, MA: MIT Press. 